ISSN:2656-4270 (Online) 1410-4466 (Print) Accredited by Ministry of Research, Technology, and Higher Education with the ranking of Sinta (S4) SK NO.28/E/KPT/2019, 26th September 2019
Buletin Penelitian Sosial Ekonomi Pertanian Fakultas Pertanian Universitas Haluoleo

2021:23(1):1-9

http://ojs.uho.ac.id/index.php/sosek

doi: http://dx.doi.org/10.37149/sosek.v23i1.15179

\title{
DEPLETION OF BIOLOGICAL ASSETS: TREATMENT AND IMPACT ON FINANCIAL STATEMENTS
}

\author{
Meta Ardiana ${ }^{1)}$, Rachma Agustina ${ }^{1^{*}}$ \\ ${ }^{1}$ Universitas Hasyim Asy'ari Tebuireng Jombang \\ ${ }^{*}$ Corresponding author: rachma.agustina1@gmail.com
}

To cite this article:

Ardiana, M., \& Agustina, R. (2021). Depletion of Biological Assets: Treatment and Impact on Financial Statements. Buletin Penelitian Sosial Ekonomi Pertanian Fakultas Pertanian Universitas Haluoleo, $23(1), 1$ - 9. doi:http://dx.doi.org/10.37149/bpsosek.v23i1.15179

Received: November 22, 2020; Accepted: February 18, 2021; Published: February 21, 2021

\begin{abstract}
This study aims to analyze the treatment of depletion or decrease in the value of biological assets and its impact on financial reports on Wibowo Farm farms in Blitar. Data collection techniques using literature study, observation, interviews, and documentation. I was checking the validity of the data through participation extension, observation persistence, and data triangulation. The result of the study was Wibowo Farm has acknowledged that there is depreciation or depletion of non-productive biological assets based on the productive value of these biological assets, if there is a death, the biological assets have also been recognized as depreciation but have not been presented in detail in the balance sheet financial statements, this is relevant to PSAK 69 which requires a calculation of impairment in the economic value of biological assets. For presentation in the financial statements of biological assets, it is reported in the balance sheet financial statements in detail on the biological assets produced. Wibowo Farm's livestock only recognizes the advantages and disadvantages when ignoring biological assets. This difference, of course, makes financial reports less reliable and relevant
\end{abstract}

Keywords: biological assets; depletion; financial statements

\section{INTRODUCTION}

As a developing country, Indonesia's basic economic activities of agriculture, plantations, and animal husbandry are still the primary sectors that help support the economy. Data from the Ministry of Agriculture from 2015-2018 shows that investment in the livestock sector has increased quite well to boost GDP. In the second quarter of 2018, FDI investment in the livestock sub-sector reached US\$ 54.3 thousand and PMDN IDR405.1 million. Similar to previous years, the increase in domestic investment in the livestock sub-sector in 2018 was still dominated by poultry commodities, which amounted to $85.1 \%$, and cattle commodities at $14.9 \%$ (Raditya, 2020). Financial statements are a significant indicator for a business entity. Financial reports are the primary management tool for cost control-financial statements as a means of economic communication between companies and users. An excellent financial report must meet several quality standards, including understandability, relevance, materiality, reliability, comparability, completeness, substance over form, sound judgment, on time, and a balance between costs and benefits (Rudianto, 2012).

One factor that determines the reliability of financial statements is the accuracy in applying accounting methods. (Kieso, Weygandt, 2002) states that it is necessary to choose the suitable accounting method, the amount and type of information that must be disclosed, and the presentation format by the rules and involves determining which alternative provides the most helpful information for decision-making purposes. The agricultural business will be different in financial statements because of the various biological assets in other companies. In the financial statements of agricultural industry activities, assets are interesting to review because they are different from manufacturing and other assets. The method of recognizing, measuring, and disclosing biological assets is different from assets in general because biological assets have unique characteristics. Namely, biological assets can produce new biological assets (Farida, 2013a). 
The transformation ability possessed by biological assets so that they become unique in accounting treatment, both in the initial recognition of acquisition, at the time of valuation and measurement, and even in the presentation of the financial statements. According to (Arimbawa et al., 2017), the stages of transformation of biological assets include growth, degeneration, production, and procreation. The Financial Accounting Standards Board has approved the Exposure Draft of PSAK 69: Agriculture at its meeting on July 29, 2015. ED PSAK 69 is valid for the financial year period starting on or after January 1, 2017. PSAK No. 69 adopts IAS 41 (International Accounting Standards) (Financial Accounting Standards Board of the Indonesian Institute of Accountants, 2015). PSAK 69 is a guideline that regulates agricultural treatment and disclosures related to agriculture or biological assets. In addition, PSAK 69 also governs the transformation experienced by biological assets consisting of growth, degeneration, production, and procreation of biological assets (Darmanto, 2016). (Maruli, Saur., Mita, 2010) states that there is an international accounting convergence that applies fair value as the basis for accounting recognition, measurement, and reporting so that a comprehensive revision of PSAK is needed. This also applies to biological assets, which most agricultural entities initially still used at historical cost. Suwardjono (2008) suggests that historical cost is the rupiah agreement or exchange price that has been recorded in the bookkeeping system. In the historical cost concept, financial statement items are calculated based on the transaction's cost (Murtianingsih \& Setiawan, 2016).

The implication of the application of PSAK 69, which is based on international standards, namely IAS 41, is that the valuation of biological assets is no longer carried out using the cost approach but is valued using the fair value approach. Fair value is the price that would be received to sell an asset or the price paid to generate a liability in an orderly transaction between market participants at the measurement date (Martani, 2016). The concept of fair value is applied because there is sustainable growth for plants or animals in agricultural companies. So we need a method that can convey value recognition related to biological assets so that the measurement can be reliable and accurate. According to (Darmanto, 2016) in its application, in Indonesia, the size using the fair value based on PSAK 69 is not suitable because it is still experiencing difficulties determining the appropriate value. When the fair value is still challenging to determine, PSAK 69 provides an option to use cost as the basis for measurement, but that is the same as returning to PSAK 16. According to IAS 41, there will be gains and losses in the financial statements when using fair value as the basis for measurement. Losses arising from appropriate value changes will result in tax payable if the tax authorities have a different interpretation from the company.

Another exciting thing about biological assets is the depletion or depreciation of assets that have life characteristics. By the attachment to the circular letter of the Chairman of Bapepam regarding guidelines for the presentation and financial reporting of livestock industry public entities. SE - 02/PM./2002 that there must be disclosure regarding the method and calculation of depletion from animals and plants with a long-lived category of more than one year. Depletion is a systematic and continuous elimination of natural resource prices (Al. Haryono, 2001). Depletion is an accounting term used for renewable natural resources. (Kieso, Weygandt, 2002) stated that the calculation of biological asset depletion is often based on the unit of production method. Accounting treatment for biological asset depletion is essential to pay attention to by agricultural entities because it can affect the productivity of biological assets and impact the company's profits or losses.

Research conducted (Nastiti, 2013) on a dairy farm KUD Boyolali City shows that the accounting treatment for biological assets is applied using the acquisition price when the company's purchase is recognized, while biological asset depletion uses several production units that are applicable regulations. Meanwhile (Pratiwi, 2017) examined the accounting treatment of biological assets, which showed difficulties in measuring biological assets based on active market values because there was no definite standard of measure. Research (Trina, 2017) entitled analysis of accounting treatment and biological asset depletion based on IAS 41 on livestock companies shows differences and types of accounting treatment according to CV. Milkindo Berkah Abadi with IAS 41. Meanwhile, the calculation of biological asset depletion is based on the production unit. Several previous studies have shown differences in the analysis of biological asset depletion, which will impact financial reporting. So this study intends to analyze the accounting treatment of biological asset depletion and its impact on financial statements.

\section{MATERIALS AND METHODS}

This research is located at the Wibowo Farm in Darugan Rt. 6 Rw. 3 Kandangan villages, Srengat sub-district, Blitar district. According to Lofland and Lofland (1984), Data sources can also be classified as follows: Main Data Sources (Primary) The main data sources are the main sources that 
can provide information, facts, reality, and descriptions related to research (Bungin, 2013). The primary sources are people whose words and actions can provide research information, data, and facts for a more specific understanding. The primary data source in this research is Mr. Erik as the source of this research. Additional data sources are the second data sources after primary data sources or main data sources. Different data sources can be in documents, archives, books, scientific magazines, dissertations, results of studies and research, or others related to the research (Ibrahim, 2018). Although it is said to be an additional data source, it cannot be ignored because, in this case, the documents used often contain data that is important for research results, both individual documents and official documents from an entity. Additional data sources from this research are documents and records owned by Wibowo Farm.

\section{The Role of Humans as Research Instruments}

In qualitative research, it is different from quantitative analysis. Qualitative research has its characteristics, namely by involving humans or the researcher in the research instrument. In qualitative research, researchers participate in determining the overall scenario (Moleong, 2017).

The role of humans as instruments here is more directed at humans or the researcher in collecting data. The purpose of the research instrument is the researcher as a data collection tool in the study (Moleong, 2017). The position of the researcher in qualitative research concurrently holds various things. Researchers as planners, implementers of data collection, researchers as data analysis, and the last researcher as a reporter for his study.

\section{Data collection technique}

This study uses data collection techniques used are literature study, observation, interviews, and documentation.

\section{Data analysis technique}

In analyzing qualitative data, several things need to be done:

1. Data reduction

According to (Sugiyono, 2016), data reduction is a step where the selection process, focusing, simplification, and data abstraction will be carried out from the records that have been obtained. Meanwhile, according to (Ibrahim, 2018) data reduction is a process where researchers need to conduct an initial study of the data that has been generated by testing the data concerning the research focus.

The data reduction step is not permissible to throw away and reduce data, but useless data can be discarded or reduced. Furthermore, related data will also be arranged according to needs. After data reduction, all relevant data has been arranged and organized according to research needs, making it easier for researchers to collect further data.

2. Data presentation

The next stage after data reduction is the data presentation stage. In this stage, the data will be reprocessed by compiling or presenting it in a series of various types. It can be shown in tables, pictures or schematics, or tables by this research. According to (Ibrahim, 2018) data presentation is a step to display, explain and also clearly present the data that has been generated. (Ibrahim, 2018) revealed that the presentation of data has two objectives as follows:

a. To ensure the data that has been obtained fit into the categories that have been determined

b. To ensure the data that has been generated is complete and has been able to answer each category that has been determined earlier.

\section{Concluding and verification}

The last stage is the stage of drawing conclusions and verification. From the previous results, researchers are expected to understand in-depth and respond to the results that have been obtained. Furthermore, the researcher will conclude the data by answering the problems and can develop a pattern of direction and cause and effect.

After completing, it is necessary to verify the data obtained to make the research results valid and can be accounted for. Verification is a repetition activity to consolidate data to streamline time quickly.

\section{Data Validity Check}

The testing of each research data is carried out by fulfilling the criteria for the validity of the data as mentioned by Ibrahim. The following techniques can be used to check the validity of the data with extending participation, the persistence of observation, and triangulation. 


\section{RESULTS AND DISCUSSION}

Wibowo Farm is one of the entities engaged in laying yam farms. Therefore, the accounting treatment carried out by Wibowo Farm is recommended by applicable regulations, namely by PSAK No. 69 or IAS 41. The following explains the accounting treatment in recognition, measurement, presentation, and disclosures related to biological assets in the form of chickens.

\section{Biological Asset Recognition}

Based on the results of interviews with Mr. Miftakhul Huda Erik Permadi as the leader, "Wibowo Farm begins to recognize biological assets at the time of purchase of DOC aged 0-1 days and is recorded in the purchase book along with proof of the transaction. The researcher records transactions made by the entity, namely the purchase of DOC in 2.500 heads for 60.000 per head. From the interview results, it can be concluded that Wibowo Farm recognizes biological assets when acquiring biological assets.

The records made by Wibowo Farm at the time of purchase are as follows: for the recognition of biological assets that have entered productive age, DOC 2500 IDR 150.000.000.00. The above transactions are accounted for in the entity's journals upon initial recognition:

Immature biological assets IDR150.000.000

Cash/ Accounts Payable

Classification or transfer of accounts for the grouping of mature and immature biological assets according to PSAK No. 69. Then the journal by PSAK No. 69 at the time of classification or group of assets are as follows:

Biological assets earn

IDR150.000.000

Immature biological assets

IDR150.000.000

In addition, in PSAK No. 69 paragraph 43, it is explained that in the financial statements of biological assets, it is recommended to provide qualitative descriptions of each group of biological assets that exist to distinguish between biological assets that are mature and immature, according to the condition of biological assets. It is used to provide information and also to view or help assess future cash flows. This is by the accounting treatment at Wibowo Farm. Mature biological assets will later be recognized as non-current assets, while immature or immature biological assets will later be identified as current assets. This is in line with research (Farida, 2013) which states the need for transactions to reclassify biological assets from immature plants to mature plants.

\section{Measurement of Biological Assets}

Biological assets at Wibowo Farm are measured using cost, determined by fair value or the price circulating in the market. The supplier's approval of the biological asset order is determined based on market prices and a mutual agreement between the supplier and the entity. According to the researcher, in this case, by the provisions of PSAK No. 69 in paragraph 12, biological assets are measured at initial recognition and the end of the reporting period at fair value fewer costs to selling so that they are measured at a real deal. The appropriate value measurement in question is based on the price of similar chickens and is considered the most profitable by the entity. But there are other provisions if fair value cannot be measured reliably. PSAK No. 69 paragraph 30 explains that biological assets can be measured at cost less accumulated depreciation and accumulated impairment losses. However, in terms of measuring biological assets, Wibowo Farm has not recorded or journalized at the time of the initial recognition transaction. The journalizing that should be made by the entity when it is measured at initial recognition is as follows. For example, Wibowo Farm makes a transaction to purchase $2,500 \mathrm{DOCs}$ for 60.000 per head. The journalizing carried out by the entity is: Immature biological assets

Cash IDR IDR150.000.000

In PSAK No. 69, the difference between fair value and cost is recognized as profit or loss at the time of initial recognition. In this case, Wibowo Farm is by PSAK No. 69. But they have not done the journalizing that should be recorded every transaction.

The following is the journalizing by PSAK No. 69 if there is a difference between the fair value and the acquisition price. there is a difference in the fair value of IDR 55,000 per chicken. While the entity and the supplier have agreed with the price of IDR 60,000 per chicken, the journalizing made by the entity is as follows

Immature biological assets

Loss on revaluation of immature biological assets

IDR137.500.000

Cash

IDR 12.500 .000

IDR150.000.000 
If there is a difference between the higher fair value and the cost, it will be recognized as a gain for the entity. Suppose the entity buys 2.500 birds for IDR55.000, while the market price of DOC is IDR 60.000 per chicken. Then the journaling carried out by the entity is as follows:

Immature biological assets

Immature biological asset revaluation profit

Cash

In terms of agricultural products in the form of eggs, Wibowo Farm measures agricultural products based on fair value. Agreements are made based on values that benefit the entity as well as the supplier. Wibowo Farm acknowledges the sale of farm products in the form of eggs. Eggs produced will be sold on the same day. Therefore, there is no journalizing of inventories of agricultural products. Wibowo Farm records the sale of farm products for every transaction, but they only record agricultural product results in the daily egg yield report.

The price of agricultural products in the farming product inventory account is usually determined based on the Cost of Production (HPP). If illustrated based on the above, the inventory of agricultural products or eggs is equal to the HPP value of IDR 162.000 .000 the journal made by the entity regarding merchandise is as follows:

Inventory of agricultural products

Cost of Production

IDR162.000.000

IDR162.000.000

\section{Presentation and Disclosure of Biological Assets}

The presentation and disclosure of biological assets on the Wibowo Farm farm are still straightforward. Namely, it is presented in the income statement to find out the profit or loss every year. In 2019 it was presented as follows:

Table 1. Wibowo farm income statement

\begin{tabular}{ll}
\hline Income from selling eggs & IDR $5.524 .848 .000,00$ \\
Income from selling rejected chickens & IDR $87.360 .000,00$ \\
Total income & IDR $5.612 .208 .000,00$ \\
Feed Load: & \\
- Corn & IDR $509.120 .000,00$ \\
- Katul & IDR $420.487 .200,00$ \\
- BKK & IDR $1.679 .650 .000,00$ \\
- MBM & IDR $397.296 .000,00$ \\
- KWS & IDR $632.000 .000,00$ \\
Total Feed Load & IDR $3.638 .553 .200,00$ \\
Electricity cost & IDR 60.000 .000 .00 \\
Employee salary costs & IDR $360.000 .000,00$ \\
Operating Expenses & IDR $75.750 .000,00$ \\
Total Load & IDR $1.486 .904 .800,00$ \\
Earnings before tax &
\end{tabular}

Source: Processed by Researchers (2021)

From the presentation above, it can be concluded that Wibowo Farm does current income from the main biological assets and discloses income from the management of agricultural products in the form of eggs. However, Wibowo farm has not announced any depletion or depreciation for biological assets, so the income statement does not appear to have depleted biological assets, increasing profit and loss, but this is still in line with the idea of IAS 41.

\section{Biological Asset Depletion}

Biological assets in agricultural activities are likened to production machines. Investments will experience depreciation, as well as biological assets that will experience depreciation. In PSAK No.69, depreciation is measured at cost less accumulated depreciation. In this case, Wibowo Farm recognizes depreciation in biological assets based on their productive value. PSAK No. 69, but Wibowo Farm has not made a journal entry to biological depreciation assets. The following is the journalizing of the depreciation of biological assets, illustrating the amortization of biological assets of IDR85,000,000:

Biological Asset Depreciation Expense

Accumulated Depreciation of Biological Assets

IDR85.000.000

In PSAK No. 69, for no longer productive assets, biological assets will be terminated in the accumulated depreciation value. Wibowo Farm said that the age of livestock that is no longer 
productive is around 85 weeks. Therefore biological assets or livestock are ready to be rejected or sold. In this case, Wibowo Farm is by PSAK No. 69. It's just that they have not done the journaling. The following is journalizing by PSAK No. 69 regarding the termination of biological assets:

Accumulated Depreciation of Biological Assets

Biological Assets

IDR85.000.000

In addition, biological assets are assets that can die because these assets are assets in the form of living things and can be affected by disease or other items. If this biological asset passes, this will be detrimental to the entity. PSAK No. 69 explains that if a biological asset dies, it will be measured at cost and reduced by accumulated depreciation for biological assets that have already matured. As many as 150 chickens died, with a book value of 35.000 per head and an estimated amortization of $5 \%$. Then the journal made by the entity after the above calculation is as follows:

Death loss IDR4.987.500
Accumulated depreciation of biological assets resulted in
Biological Assets generate
IDR 262.500
IDR5.250.000

\section{Comparative Analysis of Biological Asset Treatment}

Accounting treatment, according to Wibowo Farm, has similarities and also differences with accounting treatment according to PSAK No. 69 on agriculture, which will be presented in the following table:

Tabel 2. Comparison of the treatment of wibowo farm biological assets with PSAK 69

\begin{tabular}{|c|c|c|c|c|}
\hline No & Indicator & Wibowo Farm & PSAK No. 69 & Analysis \\
\hline \multirow[t]{3}{*}{1} & \multirow[t]{3}{*}{ Recognition } & $\begin{array}{l}\text { Purchasing DOC is the } \\
\text { beginning of a biological } \\
\text { set }\end{array}$ & $\begin{array}{lr}\text { Agricultural companies } \\
\text { recognize or } & \text { control } \\
\text { biological } & \text { assets } \\
\text { based on red past } \\
\text { transactions }\end{array}$ & 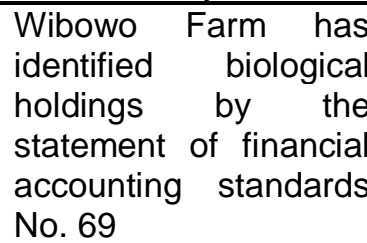 \\
\hline & & $\begin{array}{l}\text { The economic life of } \\
\text { biological assets at } \\
\text { Wibowo Farm is } \pm 76 \\
\text { weeks, which means } \\
\text { more than one year. } \\
\text { This can be interpreted } \\
\text { that biological assets } \\
\text { provide economic } \\
\text { benefits in the future or } \\
\text { the following year } \\
\text { because biological } \\
\text { assets will continue to } \\
\text { produce and produce } \\
\text { agricultural products as } \\
\text { feedback. }\end{array}$ & $\begin{array}{l}\text { Relates the economic } \\
\text { life to the benefits that } \\
\text { the biological asset will } \\
\text { flow to the entity }\end{array}$ & $\begin{array}{l}\text { In this case, both are } \\
\text { the same because } \\
\text { Wibowo Farm and } \\
\text { PSAK No. } 69 \text { made } \\
\text { initial recognition the } \\
\text { same asset in general. }\end{array}$ \\
\hline & & $\begin{array}{l}\text { Wibowo Farm has } \\
\text { recognized biological } \\
\text { assets by distinguishing } \\
\text { between immature and } \\
\text { mature biological assets }\end{array}$ & $\begin{array}{l}\text { Biological assets } \\
\text { should be classified } \\
\text { according to their } \\
\text { ability to generate and } \\
\text { non-productive. }\end{array}$ & $\begin{array}{l}\text { It is by PSAK No. 69, } \\
\text { just different terms }\end{array}$ \\
\hline \multirow[t]{2}{*}{2} & \multirow[t]{2}{*}{ Measurement } & $\begin{array}{l}\text { Measurement of } \\
\text { biological assets } \\
\text { purchased from outside } \\
\text { parties at Wibowo Farm } \\
\text { is based on a mutually } \\
\text { agreed purchase price. }\end{array}$ & $\begin{array}{l}\text { Biological assets are } \\
\text { measured at market } \\
\text { value, or they can also } \\
\text { be at cost when the } \\
\text { biological assets are } \\
\text { acquired }\end{array}$ & $\begin{array}{l}\text { By PSAK No. } 69, \\
\text { biological assets can } \\
\text { be recognized at fair } \\
\text { value or cost }\end{array}$ \\
\hline & & $\begin{array}{l}\text { For biological systems } \\
\text { that have already been } \\
\text { produced, there is no } \\
\text { specific calculation yet }\end{array}$ & $\begin{array}{l}\text { The measurement of } \\
\text { biological assets that } \\
\text { have been produced is } \\
\text { based on fair value } \\
\text { fewer costs incurred to }\end{array}$ & $\begin{array}{l}\text { In this case, Wibowo } \\
\text { Farm is not by PSAK } \\
\text { No. } 69 \text { because there } \\
\text { is no detailed } \\
\text { calculation of the }\end{array}$ \\
\hline
\end{tabular}


Tabel 2. Comparison of the treatment of wibowo farm biological assets with PSAK 69

\begin{tabular}{|c|c|c|c|c|}
\hline No & Indicator & Wibowo Farm & PSAK No. 69 & Analysis \\
\hline & & & sell & $\begin{array}{l}\text { biological assets that } \\
\text { produce }\end{array}$ \\
\hline & & $\begin{array}{l}\text { Wibowo farm also } \\
\text { recognizes gains and } \\
\text { losses when there is a } \\
\text { change in fair value or } \\
\text { market price }\end{array}$ & $\begin{array}{l}\text { Changes in fair value, } \\
\text { both those that result } \\
\text { in gains or losses, are } \\
\text { reported in the } \\
\text { comprehensive } \\
\text { financial statements }\end{array}$ & $\begin{array}{l}\text { In this case, Wibowo } \\
\text { Farm has similarities, } \\
\text { namely that it has } \\
\text { recognized the } \\
\text { advantages and } \\
\text { disadvantages of } \\
\text { biological assets. Still, } \\
\text { there is a difference } \\
\text { because Wibowo Farm } \\
\text { only recognizes } \\
\text { benefits and penalties } \\
\text { at the time of rejecting } \\
\text { biological assets. } \\
\text { Wibowo Farm has } \\
\text { periodically } \\
\text { reassessed biological } \\
\text { assets }\end{array}$ \\
\hline & & $\begin{array}{l}\text { Wibowo Farm admits } \\
\text { that there is a decrease } \\
\text { in productive biological } \\
\text { assets. }\end{array}$ & $\begin{array}{l}\text { Measurement of } \\
\text { biological assets using } \\
\text { the cost at the end of } \\
\text { the period must be } \\
\text { reduced } \\
\text { impairment. }\end{array}$ & $\begin{array}{l}\text { This is by the entity } \\
\text { with PSAK No. } 69 \text { in } \\
\text { terms of depreciation. }\end{array}$ \\
\hline & & $\begin{array}{l}\text { If there is a biological } \\
\text { asset that dies, it is } \\
\text { considered as } \\
\text { depreciation. And every } \\
\text { biological asset death is } \\
\text { recorded in a diary. }\end{array}$ & $\begin{array}{l}\text { PSAK No. } 69 \text { explains } \\
\text { if there is a risk of } \\
\text { causing an expense, } \\
\text { and the rules of PSAK } \\
\text { will present additional } \\
\text { income No. } 1\end{array}$ & $\begin{array}{l}\text { In this case, the entity } \\
\text { is by PSAK No. } 69 \text {. }\end{array}$ \\
\hline 3 & Presentation & $\begin{array}{lc}\text { Wibowo } & \text { Farm has } \\
\text { presented } & \text { biological } \\
\text { assets in the balance } \\
\text { sheet } \\
\text { statements } \text { (statemential } \\
\text { of financial position). }\end{array}$ & $\begin{array}{l}\text { PSAK } 69 \text { regulates the } \\
\text { presentation of } \\
\text { property, plant, and } \\
\text { equipment in the } \\
\text { statement of financial } \\
\text { position. By grouping } \\
\text { in the fixed assets } \\
\text { group while still doing } \\
\text { the breakdown based } \\
\text { on biological assets } \\
\text { that produce and do } \\
\text { not produce. }\end{array}$ & $\begin{array}{l}\text {-According to PSAK } \\
\text { No. } 69 \text {, but has not } \\
\text { been equipped with } \\
\text { the classification of } \\
\text { biological assets that } \\
\text { are productive and } \\
\text { immature }\end{array}$ \\
\hline 4 & Disclosure & $\begin{array}{l}\text { Wibowo Farm records } \\
\text { biological assets in the } \\
\text { sales book or production } \\
\text { income }\end{array}$ & $\begin{array}{l}\text { There should be a } \\
\text { separater register } \\
\text { detailing biological } \\
\text { assets }\end{array}$ & $\begin{array}{l}\text { Relevant to PSAK No. } \\
69 .\end{array}$ \\
\hline & & $\begin{array}{l}\text { Wibowo Farm has not } \\
\text { recorded details of the } \\
\text { number of biological } \\
\text { assets based on type or } \\
\text { age. }\end{array}$ & $\begin{array}{l}\text { There are details on } \\
\text { the number of } \\
\text { biological assets } \\
\text { according to their type } \\
\text { or age, }\end{array}$ & $\begin{array}{l}\text { Not by PSAK No. } 69, \\
\text { because it has not } \\
\text { included details of the } \\
\text { number of biological } \\
\text { assets according to } \\
\text { age and type in the } \\
\text { financial statements } \\
\text { made. }\end{array}$ \\
\hline
\end{tabular}


Tabel 2. Comparison of the treatment of wibowo farm biological assets with PSAK 69

\begin{tabular}{|c|c|c|c|c|}
\hline No & Indicator & Wibowo Farm & PSAK No. 69 & Analysis \\
\hline & & $\begin{array}{l}\text { Wibowo Farm has not } \\
\text { done a quantitative } \\
\text { descriptive of biological } \\
\text { assets in its financial } \\
\text { statements. }\end{array}$ & $\begin{array}{l}\text { PSAK No. } 69 \text { requires } \\
\text { a } \\
\text { descriptive explanation } \\
\text { of agricultural assets }\end{array}$ & $\begin{array}{l}\text { This is not by PSAK } \\
\text { No. } 69\end{array}$ \\
\hline & & $\begin{array}{l}\text { Wibowo Farm records } \\
\text { the number of biological } \\
\text { assets owned and } \\
\text { agricultural products in } \\
\text { the sales book or daily } \\
\text { agricultural product } \\
\text { results. }\end{array}$ & $\begin{array}{l}\text { Statement of Financial } \\
\text { Accounting Standards, } \\
\text { paragraph } 46 \text { states } \\
\text { that as an alternative, } \\
\text { when an agricultural } \\
\text { entity does not } \\
\text { disclose biological } \\
\text { assets anywhere in the } \\
\text { financial statements } \\
\text { that are distributed to } \\
\text { the public, the entity } \\
\text { can describe the } \\
\text { nature of its activities } \\
\text { involving biological } \\
\text { assets and record it for } \\
\text { the period. }\end{array}$ & $\begin{array}{l}\text { In this case, Wibowo } \\
\text { Farm is by PSAK } 69 \\
\text { because the entity has } \\
\text { recorded the biological } \\
\text { assets it owns and the } \\
\text { output of agricultural } \\
\text { products during that } \\
\text { period. }\end{array}$ \\
\hline
\end{tabular}

From the comparison table above, there are still differences in accounting treatment applied by Wibowo Farm with PSAK 69, including differences in accounting terms at the initial recognition of biological assets. In this case, the difference in measurement, Wibowo Farm, is not by PSAK 69 because there is no detailed calculation of biological assets that produce. Wibowo Farm only recognizes the existence of gains and losses at the time of the dismissal of biological assets.

This difference certainly makes financial statements less reliable and relevant. This refers to the research results (Putri, 2014), which states that financial statements that are less reliable will provide misleading information for users in making economic decisions.

\section{CONCLUSIONS}

Recognition in Wibowo Farm recognizes that biological assets began at the time of purchase of DOC aged 0-1 days and reclassified from immature assets to mature ones. The measurement of biological assets uses the acquisition price determined by fair value or prices circulating in the market. The presentation of biological assets has not been made into the financial statements it has made. Disclosure, has recorded biological assets in the sales book or production income and recorded the number of biological assets owned and also agricultural products in the sales book or daily agricultural products, but has not recorded details of the number of biological holdings by type or age and has not carried out quantitative descriptive of biological assets in its financial statements. Wibowo Farm has recognized the existence of depreciation or depletion of non-productive biological holdings based on the productive value of these biological assets. In the event of the death of biological assets, it has also been recognized as depreciation but has not been presented in detail in the balance sheet financial statements. This is relevant to PSAK 69, which requires calculating the economic value impairment of biological assets. For the presentation in the financial statements of biological assets, it has been reported in the balance sheet financial statements in detail on the biological assets that produce. Wibowo Farm only recognizes the existence of gains and losses at the time of the dismissal of biological assets. This difference certainly makes the financial statements less reliable and relevant

\section{REFERENCES}

Al. Haryono, J. (2001). Dasar - Dasar Akuntansi Jilid 2. Bagian Penerbitan Sekolah Tinggi Ilmu YKPN.

Arimbawa, P. M., Sinarwati, N. K., \& ... (2017). Perlakuan Akuntansi Aset Biologis pada Organisasi Kelompok Tani Ternak Sapi Kerta Dharma DEsa Tukadmungga Kecamatan Buleleng 
$\begin{array}{lllllll}\text { Kabupaten } & \text { Buleleng. } & \ldots & \text { Mahasiswa } & \text { Akuntansi }\end{array}$ https://ejournal.undiksha.ac.id/index.php/S1ak/article/view/9045

Bungin, B. (2013). Penelitian Kualitatif Komunikasi, Ekonomi, Kebijakan Publik, dan IImu Sosial lainnya (1st ed.). Kencana Prenada Media Group.

Darmanto, S. (2016). Perbandingan Perlakuan Aset Biologis Berdasarkan Internasional Accounting Standar 41 dengan PSAK 69 pada PTPN XII UUS Gunung Gumitir. Jurnal Fakultas Ekonomi Jember: Universitas Muhammadiyah Jember, Juli 2016.

Dewan Standar Akuntansi Keuangan Ikatan Akuntan Indonesia. (2015). Exposure Draft PSAK 69: Agrikultur. Akuntansi Keuangan, 69(1).

Farida, I. (2013a). Analisis Perlakuan Akuntansi Aset Biologis Berdasarkan International Accounting Standard 41 Pada Pt. Perkebunan Nusantara Vii (Persero). Jurnal Akuntansi AKUNESA, 2(1), 84-90.

Farida, I. (2013b). Analisis Perlakuan Akuntansi Aset Biologis Berdasarkan International Accounting Standard 41 Pada Pt. Perkebunan Nusantara Vii (Persero). Jurnal Akuntansi AKUNESA, 2(1), $1-24$.

Ibrahim. (2018). Metodologi Penelitian Kualitatif, Panduan Penelitian Beserta Contoh Proposal Kualitatif. Alfabeta.

Kieso, Weygandt, dan W. (2002). Akuntansi Intermediate (X). Erlangga.

Martani, D. dkk. (2016). Akuntansi Keuangan Menengah Berbasis PSAK (ed. 2, buku 1) (2nd ed.). Salemba Empat.

Maruli, Saur., Mita, A. F. (2010). Analisis Pendekatan Nilai Wajar dan Nilai Historis Dalam Penilaian Aset Biologis: Tinjauan Kritis Rencana Adopsi IAS 41. Simposium Nasional Akuntansi XII Purwokerto. http://lib.ibs.ac.id/materi/Prosiding/SNA XIII (simposium nasional akuntansi XIII) Unsud/makalah/AKPM_52.pdf

Moleong, L. J. (2017). Metode Penelitian Kualitatif, Cet. 36. PT. Remaja Rosdakarya Offset.

Murtianingsih, M., \& Setiawan, A. H. (2016). the Implementation of Fair Value on Short Term Assesment of Biological Assets. Journal of Accounting and Business Education, 1(1), 40. https://doi.org/10.26675/jabe.v1i1.6728

Nastiti, D. H. (2013). Deplesi aset biologis pada peternakan sapi perah kud Kota boyolali.

Pratiwi, W. (2017). Analisis Perlakuan Akuntansi Aset Biologis Berbasis Psak-69 Agrikultur Pada Pt.Perkebunan Nusantara Xii Kalisanen Kabupaten Jember. Prosiding Seminar Nasional Dan Call For Paper Ekonomi Dan Bisnis (SNAPER-EBIS 2017), 2017, 140-150.

Putri, S. (2014). Analisis Perbandingan Pelaporan dan Pengungkapan Aset Biologis Sebelum dan Setelah Penerapan IAS (International Accounting Standard) 41 Pada PT. Astra Agro Lestari, Tbk. Jurnal Akuntansi Unesa, 2(2), 1-21.

Raditya, D. (2020). Ringkasan Dunia Peternakan Indonesia Selama Beberapa Tahun Terakhir. Creative Hub, Fisipol UGM. https://chub.fisipol.ugm.ac.id/2020/04/28/ringkasan-duniapeternakan-indonesia-selama-beberapa-tahun-terakhir/

Rudianto. (2012). Pengantar Akuntansi Konsep \& Teknik Penyusunan Laporan Keuangan. Erlangga.

Sugiyono. (2016). Metodologi Penelitian Kuantitatif, Kualitatif, dan R\&D. CV Alfabeta.

Trina, Z. I. (2017). Analisis Perlakuan Akuntansi Dan Deplesi Aset Biologis Berdasarkan las 41 Pada Perusahaan Peternakan (Studi Kasus Pada CV. Milkindo Berka Abadi Kepanjen). Universitas Islam Negeri (UIN) Maulana Malik Ibrahim Malang. 